\title{
ANALISIS KEMAMPUAN BERPIKIR KRITIS SISWA SMA PADA MATERI MOMENTUM DAN IMPULS
}

\author{
Anggia Rizki Permata ${ }^{\text {a) }}$ Muslim, Iyon Suyana \\ Universitas Pendidikan Indonesia, Fakultas Pendidikan Matematika dan Ilmu Pengetahuan Alam, \\ Departemen Penidikan Fisika, Jl. Dr. Setiabudhi 229 Bandung 40154, Indonesia \\ Email: a)anggiadinda@gmail.com
}

\begin{abstract}
Abstrak
Penelitian ini bertujuan mendeskripsikan salah satu kemampuan abad 21 yaitu kemampuan berpikir kritis (critical thinking) siswa SMA pada materi Momentum dan Impuls. Subyek penelitian ini adalah siswa SMA tahun ajaran 2018/2019 yang berjumlah 20 orang. Kemampuan berpikir kritis mengacu pada indikator kemampuan berpikir kritis Ennis (2011). Instrumen terdiri dari 25 butir soal pilihan ganda yang telah divalidasi oleh ahli. Hasil penelitian menunjukan kemampuan memberikan penjelasan dasar, membangun keterampilan dasar, inferensi, membuat penjelasan lebih lanjut, strategi dan taktik. Kemampuan berpikir kritis siswa masih tergolong rendah dan kemampuan membuat penjelasan lebih lanjut memiliki nilai yang lebih rendah dibandingkan kemampuan lainnya.
\end{abstract}

Kata-kata kunci: Kemampuan berpikir kritis, Siswa SMA.

\begin{abstract}
This study aims to describe one of the capabilities of the 21st century, critical thinking of high school students on momentum and impulse concepts for 2018/2019 the academic year. The subject of this study were senior high school students totaling 20 people. Critical thinking ability refers to the indicators of Ennis's critical thinking skills (2011). The instrument consists of 25 questions with multiple choice that have been validated by experts. The results of the study show the ability to provide basic explanations, build basic skill, inference, making further explanations, strategies and tactics. Students' critical thinking skills are still relatively low, the ability making further explanations has a lower value than other abilities.
\end{abstract}

Keywords: Critical thinking ability, high school students.

\section{PENDAHULUAN}

Kemendikbud dalam Peraturan Menteri Pendidikan dan Kebudayaan Republik Indonesia nomor 81A tahun 2013 [1] menyatakan bahwa kegiatan pembelajaran merupakan suatu proses pendidikan yang memberikan kesempatan kepada siswa untuk mengembangkan potensi yang dimilikinya agar lebih baik lagi. Kemendikbud dalam Peraturan Menteri Pendidikan dan Kebudayaan Republik Indonesia nomor 20 tahun 2013 [2] menyatakan bahwa setiap lulusan suatu satuan pendidikan haruslah memiliki kompetensi pada tiga dimensi yaitu sikap, pengetahuan, dan keterampilan. Pada dimensi keterampilan, siswa diharapkan memiliki keterampilan berpikir dan bertindak diantaranya kreatif, produktif, kritis, mandiri, kolaboratif, dan komunikatif melalui pendekatan ilmiah. Berdasarkan uraian tersebut, siswa dituntut untuk memiliki keterampilan, salah satu keterampilan yang harus dimiliki siswa adalah kemampuan berpikir kritis [3]. Lau dan Chan [4] mengatakan bahwa kemampuan berpikir kritis adalah kemampuan untuk berpikir jernih dan rasional menganai 
apa yang harus dilakukan atau apa yang harus dipercaya, termasuk kemampuan untuk terlibat dalam pemikiran reflektif dan mandiri.

Berdasarkan hasil analisis Rahmawati [5] mengenai studi empat tahunan Trends in International Mathematics and Science Study (TIMSS), Indonesia berada pada urutan ke 6 dari bawah. Indonesia juga mengikuti studi PISA pada tahun 2012, dan Indonesia berada pada urutan ke 64 dari 65 negara yang diuji. Dalam soal PISA terdiri dari 6 level, level 1 sampai 3 disebut dengan kemampuan berpikir tingkat rendah (LOTS), sementara level 4 sampai 6 disebut dengan kemampuan berpikir tingkat tinggi (HOTS). Berdasarkan hasil PISA, ditemukan bukti bahwa siswa Indonesia hanya mampu mengerjakan soal-soal pada level 1 sampai 3 saja, sementara Negara lain banyak yang sudah mencapai level 4,5, ataupun 6. Berdasarkan hasil TIMSS dan PISA tersebut dikatakan bahwa siswa Indonesia hanya menguasai soal-soal tingkat rendah yang bersifat rutin, komputasi sederhana, serta mengukur pengetahuan akan fakta yang berkonteks keseharian. Siswa Indonesia kurang menguasai soal - soal tingkat tinggi (HOTS) yang diantaranya menuntut siswa untuk berpikir analisis, kreatif dan kritis. Hal ini disebabkan oleh tiga faktor utama, yaitu struktur sistem pendidikan saat ini, kompleksitas keterampilan siswa, dan kompetensi guru dalam mengajar [6].

Kowiyah [7] mengatakan bahwa berpikir kritis adalah mode berpikir mengenai hal, substansi atau masalah apa saja, dimana si pemikir meningkatkan kualitas pemikirannya dengan menangani secara terampil struktur-struktur yang melekat dalam pemikiran dan menerapkan standar-standar intelektual padanya. Pendapat lain juga diberikan oleh Treffinger dkk [8] bahwa kemampuan berpikir kritis melibatkan kemampuan memeriksa suatu kemungkinan dengan hati-hati, adil dan konstruktif, kemudian memfokuskan pikiran serta tindakan anda dengan: mengatur dan menganalisis kemungkinan; memperbaiki dan mengembangkan kemungkinan yang menjanjikan; menentukan peringkat atau memprioritaskan pilihan; dan memilih atau memutuskan pilihan yang tepat. Dalam referensi [8] juga mengatakan bahwa berpikir kritis sering juga disebut dengan berpikir konvergen, yaitu suatu proses dari berbagai ide lalu menyatukannya menjadi sebuah tujuan atau hasil. Menurut Ennis [9], berpikir kritis adalah berpikir secara beralasan dan reflektif dengan menekankan pada pembuatan keputusan tentang apa yang harus dipercayai atau dilakukan [10].

Berdasarkan pada hal tersebut, penelitian ini bertujuan untuk memperoleh gambaran kemampuan berpikir kritis siswa SMA pada materi pembelajaran fisika yaitu momentum dan impuls berdasarkan pada aspek kemampuan berpikir kritis pada referensi [9]. Dengan penelitian ini, diharapkan guru dapat merancang kegiatan pembelajaran yang dapat melatihkan aspek - aspek kemampuan berpikir kritis bagi siswanya.

\section{METODE PENELITIAN}

Metode yang digunakan oleh peneliti dalam penelitian ini adalah metode deskriptif kualitatif. Partisipan yang terlibat dalam penelitian ini adalah siswa yang sudah mempelajari materi Momentum dan Impuls, sehingga subyek yang dilipih dalam penelitian ini adalah siswa kelas X IPA dengan materi fisika yang dipilih adalah Momentum dan Impuls. Sampel dari penelitian ini sebanyak satu kelas atau 21 orang siswa, penentuan sampel penelitian ini dipilih secara convenience. Arikunto [11] berpendapat bahwa instrumen yang digunakan dalam penelitian ini adalah instrumen tes bentuk pilihan ganda. Instrumen tes merupakan serentetan pertanyaan atau latihan serta alat lain yang digunakan untuk mengukur keterampilan, pengetahuan intelegensi, kemampuan atau bakat yang dimiliki oleh individi atau kelompok. Sebelum instrumen tes kemampuan berpikir kritis yang berjumlah 25 butir soal diujikan pada siswa, penulis melakukan judgement terhadap instrument tes kepada ahli. Dalam hal ini, penulis meminta judgement dari tiga orang ahli.

Selain itu, penelitian ini memilih materi momentum dan impuls karena materi tersebut penting untuk dipelajari dan juga dapat diaplikasikan dalam kehidupan sehari-hari. Alasan lainnya, diantaranya:

- Kompetensi dasar pada materi momentum dan impuls yang harus dimiliki siswa yaitu "menerapkan" yang berada pada ranah kognitif C3 sehingga peneliti mampu membuat indikator pencapaian kompetensi (IPK) yang lebih tinggi dari C3. Seperti yang diketahui bahwa kemampuan berpikir kritis merupakan kemampuan berpikir tingkat tinggi yang ditandai dengan siswa mampu mencapai ranah kognitif C4, C5, dan C6. 
- Model pembelajaran yang digunakan adalah model pembelajaran Problem Solving, sehingga perlu menyajikan masalah yang nyata. Dalam hal ini, materi momentum dan impuls banyak diaplikasikan dalam kehidupan sehari-hari sehingga dapat menjadikan permasalahan yang dibuat menjadi lebih nyata.

- Salah satu materi pembelajaran yang harus dicapai atau dituntaskan oleh peserta didik pada mata pelajaran fisika di SMA berdasar kepada kurikulum 2013 revisi (KURTILAS Revisi).

\section{HASIL PENELITIAN DAN PEMBAHASAN}

\section{Hasil}

Penulis melakukan pengumpulan data dengan instrumen tes kemampuan berpikir kritis yang mengacu pada kelima aspek yang telah diperkenalkan [9]. TABEL 1 menyajikan penyebaran indikator soal dan indikator KBK dan TABEL 2 menyajikan hasil tes kemampuan berpikir kritis siswa sebagai berikut:

TABEL 1. Penyebaran indikator soal dan indikator KBK

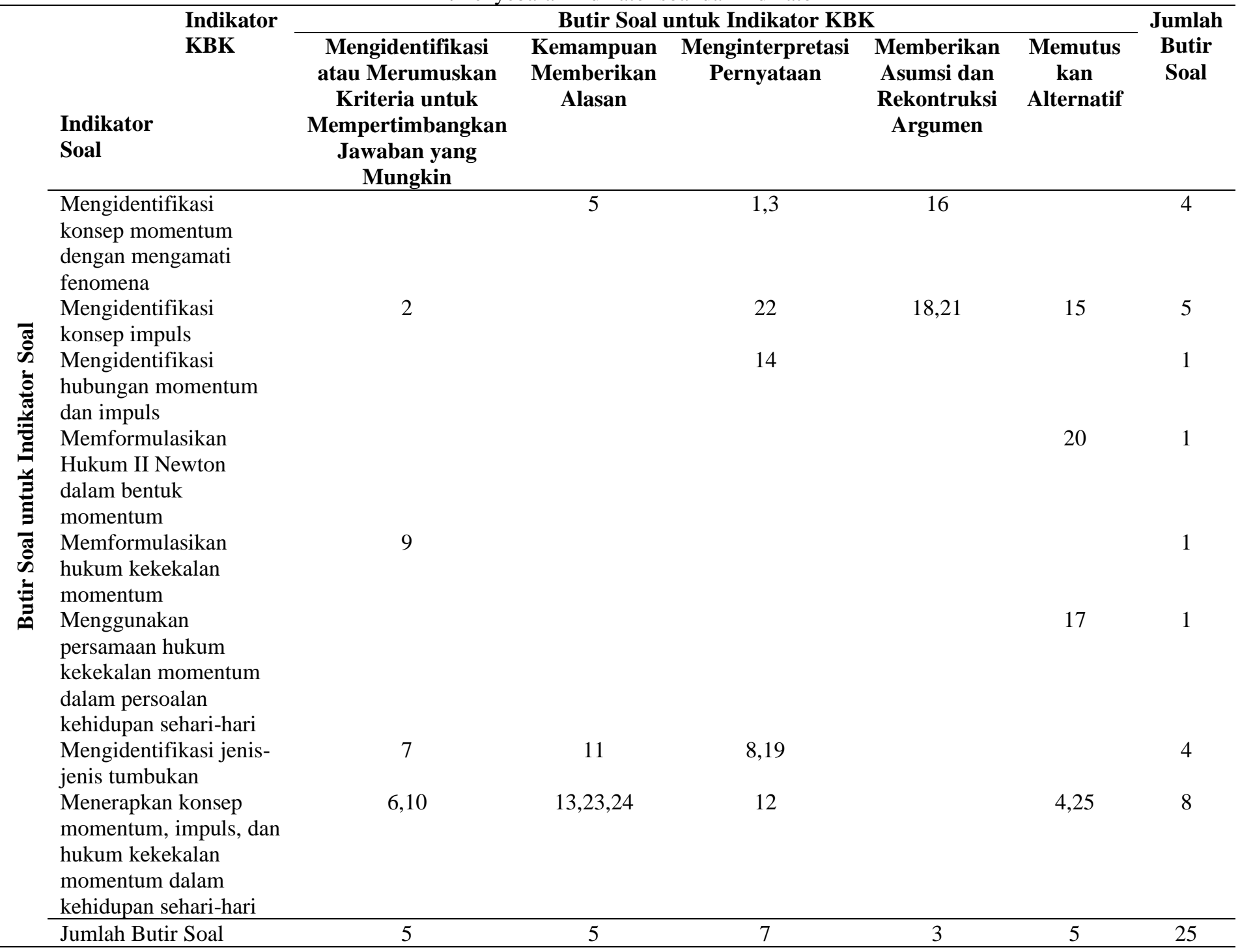


TABEL 2. Hasil tes KBK berdasarkan aspek KBK dari Ennis

\begin{tabular}{clccc}
\hline No. & \multicolumn{1}{c}{ Aspek KBK } & $\begin{array}{c}\text { Jumlah butir } \\
\text { soal }\end{array}$ & $\begin{array}{c}\text { Skor tiap } \\
\text { aspek }\end{array}$ & $\begin{array}{c}\text { Persentase } \\
\text { siswa (\%) }\end{array}$ \\
\hline 1 & Memberikan penjelasan dasar & 5 & 46 & 36,80 \\
2 & Membangun keterampilan dasar & 5 & 51 & 40,80 \\
3 & Inferensi & 7 & 56 & 32,00 \\
4 & Membuat penjelasan lebih lanjut & 3 & 23 & 30,67 \\
5 & Strategi dan taktik & 5 & 46 & 36,80 \\
\hline Rata - rata persentase siswa (\%) & & & 35,41 \\
\hline
\end{tabular}

Berdasarkan TABEL 2, dapat kita lihat bahwa pada setiap aspek kemampuan berpikir kritis, ratarata persentase kemampuan berpikir kritis siswa adalah 35,41\%, dapat kita interpretasikan bahwa kemampuan berpikir kritis siswa ini masih perlu ditingkatkan. Nuryanti [12] menjelaskan bahwa guru harus lebih kreatif dalam merancang dan mengembangkan perangkat pembelajaran guna meningkatkan kemampuan berpikir kritis siswa hingga menjadi habit.

\section{Pembahasan}

Berdasarkan TABEL 1, dapat kita interpretasikan bahwa kemampuan berpikir kritis siswa ini masih perlu ditingkatkan. Hal ini sejalan dengan hasil analisis pada [5] tentang perolehan peringkat siswa Indonesia pada hasil TIMSS dan PISA yang menyatakan bahwa siswa Indonesia masih kurang menguasai soal-soal tingkat tinggi yang menuntut siswa untuk dapat berpikir kritis. Arini dan Juliadi [13] juga mengemukakan dalam penelitiannya bahwa kemampuan berpikir kritis siswa berada pada kategori rendah, selain itu berdasarkan wawancara dengan siswa, Penelitian tersebut [13] mengatakan bahwa siswa tidak terbiasa dengan soal-soal dengan indikator kemampuan berpikir kritis sehingga siswa enggan menyelesaikan soal ketika menemukan suatu hambatan. Fatmawati, Mardiyana dan Triyanto [14] dalam penelitiannya menyatakan bahwa tingkat berpikir kritis siswa berdasarkan TBK Polya ada pada tingkat kemampuan berpikir kritis ke satu (TBK1), dalam hal ini siswa sudah mampu memahami masalah, namun siswa belum mampu untuk mendeteksi bias, tidak mampu mengungkap argumen yang jelas, tidak mampu memeriksa kembali jawaban, siswa tidak menemukan cara lain dalam menyelesaikan masalah, dan tidak mampu menarik kesimpulan. Jika dianalisis lagi, ada beberapa kesamaan TBK Polya dengan kemampuan berpikir kritis menurut Ennis, sehingga bisa dikatakan bahwa siswa baru mampu berpikir kritis pada satu dari lima aspek KBK Ennis, dan tentunya hal ini juga menyatakan bahwa kemampuan berpikir kritis siswa masih perlu dikembangkan.

Ennis [9] mengembangkan berpikir kritis ke dalam dua aspek yakni aspek pembentukan watak (dispositions) dan aspek kemampuan (ability). Pada penelitian ini, aspek keterampilan berpikir kritis yang akan menjadi fokus penelitian adalah domain ability. Dan digunakan satu indikator pada tiap aspek keterampilan berpikir kritis.

\section{Aspek KBK ke-1 : Memberikan penjelasan dasar}

Dari ke lima soal tersebut, tidak ada satu pun siswa yang dapat menjawab pertanyaan nomor 9 dengan benar. Namun untuk keempat soal lainnya, beberapa siswa dapat menjawab dengan benar, dengan persentase siswa yang dapat menjawab benar pada aspek ini adalah $36,80 \%$. Berikut butir soal nomor 9 yang disajikan dalam GAMBAR 1: 
Diketahui terdapat dua buah balok pada suatu lintasan tanpa gesekan. Balok 1 dengan massa $\mathrm{m}_{1}$ mula - mula bergerak dengan kelajuan $\mathrm{v}_{0}$ lalu menumbuk dan menempel pada balok 2 bermassa $m_{2}=9 m_{1}$ yang mula - mula diam. Kelajuan kedua balok setelah tumbukan adalah ....
A. $v_{0}$
C. $\frac{8}{9} v_{0}$
E. $\frac{1}{10} v_{0}$
B. $\frac{9}{10} v_{0}$
D. $\frac{1}{9} v_{0}$

GAMBAR 1. Butir soal nomor 9

Berdasarkan persentase tersebut, kemampuan memberikan penjelasan dasar siswa masih perlu dikembangkan. Guru diminta untuk menciptakan pembelajaran yang dapat mengembangkan aspek tersebut, seperti meminta siswa untuk mengidentifikasi atau merumuskan pertanyaan, mengidentifikasi atau merumuskan kriteria untuk menilai jawaban yang mungkin, menyimpan situasi yang ada serta pertanyaannya di dalam pikiran, dan lainnya dalam referensi [9].

\section{Aspek KBK ke-2 : : Membangun keterampilan dasar}

Kemampuan membangun keterampilan dasar siswa juga masih perlu dikembangkan, karena persentase siswa yang menguasai aspek ini adalah 40,80\%. Banyak cara yang dapat digunakan oleh guru dalam mengembangkan aspek ini, salah satunya dengan memberikan siswa pertanyaan yang meminta siswa untuk memberikan alasan terhadap pilihannya dalam referensi [9].

\section{Aspek KBK ke-3 \\ : Inferensi}

Inferensi artinya suatu tindakan menyimpulkan sesuatu berdasarkan alasan yang logis. Pada aspek ini juga kemampuan siswa dalam inferensi masih rendah yaitu hanya 32,00\% siswa yang mampu menguasai aspek tersebut. Guru dapat mengembangkan kemampuan inferensi siswa misalnya dengan meminta siswa menginterpretasikan suatu pertanyaan, membuat hipotesis, menarik kesimpulan dari suatu demonstrasi, dan lainnya dalam referensi [9].

\section{Aspek KBK ke-4 : : : Membuat penjelasan lebih lanjut}

Dari kelima aspek KBK, aspek KBK yang memiliki skor terendah adalah aspek membuat penjelasan lebih lanjut. Berikut disajikan contoh soal untuk aspek membuat penjelasan lebih lanjut:

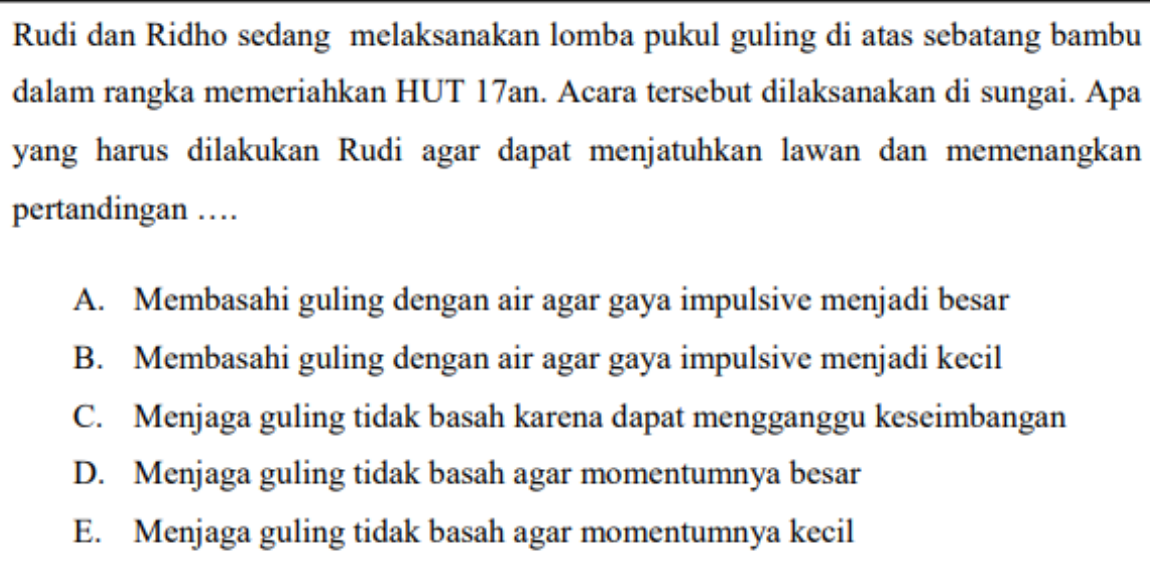

A. Membasahi guling dengan air agar gaya impulsive menjadi besar

B. Membasahi guling dengan air agar gaya impulsive menjadi kecil

C. Menjaga guling tidak basah karena dapat mengganggu keseimbangan

D. Menjaga guling tidak basah agar momentumnya besar

E. Menjaga guling tidak basah agar momentumnya kecil

GAMBAR 2. Contoh soal tes KBK 
Hanya 6 dari 21 siswa yang dapat menjawab pertanyaan di atas, hal ini menunjukan bahwa aspek membuat penjelasan lebih lanjut ini masih rendah. Siswa tidak terbiasa menjawab pertanyaan seperti GAMBAR 2 karena guru tidak membiasakan siswa untuk berpikir kritis di dalam proses pembelajaran. Guru perlu mengembangkan aspek ini misalnya dengan memberikan rekontruksi argumen, meminta siswa untuk memberikan penjelasan lebih lanjut, atau mendefinisikan sesuatu, dalam referensi [9].

\section{Aspek KBK ke-5 : : Strategi dan taktik}

Sama seperti ke empat aspek lainnya, kemampuan siswa untuk menguasai aspek ini juga tidak lebih dari 50\%, yaitu hanya 36,80\%. Maka dari itu, guru harus mampu mengembangkan kemampuan strategi dak taktik siswa, Ennis [9] menjelasakan bahwa guru dapat mengembangkan aspek tersebut dengan meminta siswa memutuskan hal-hal yang akan dilakukan seperti membuat langkkah-langkah penelitian, membuat review pada tiap pertemuan, ataupun yang lainnya dalam referensi.

Dilihat dari nilai persentase rata-rata, didapatkan hasil 35,41\% yang dapat dimasukan ke dalam kriteria rendah-sedang, menurut peneliti hasil ini dipengaruhi juga oleh teknik pengambilan datanya, sampel sebaiknya tidak diambil secara convenience, karena hasil yang didapatkan menjadi kurang mewakili populasi.

Selanjutnya, sejalan dengan penelitian Nuryanti [12]; Sari [15]; dan Fatmawati [16] yang menyimpulkan bahwa masih rendahnya kemampuan berpikir kritis siswa sehingga perlunya suatu pembelajaran yang dapat mengembangkan kemampuan berpikir kritis siswa. Padahal Kemdikbud [1] menjelaskan bahwa siswa diharapkan memiliki keterampilan berpikir dan bertindak yang salah satunya adalah berpikir kritis. Banyak model pembelajaran yang dapat membantu siswa dalam meningkatkan kemampuan berpikir kritisnya, di antaranya: menerapkan model pembelajaran problem solving [17]; mengimplementasikan strategi writing to learn [18]; pengembangan pembelajaran elektronik [19]. Santyasa [20] juga menjelaskan bahwa dampak dari pembelajaran dalam model pembelajaran Problem Solving ini adalah pemahaman, keterampilan berpikir kritis dan kreatif, kemampuan pemecahan masalah, kemampuan komunikasi, serta keterampilan menggunakan pengetahuan secara bermakna.

\section{SIMPULAN}

Berdasarkan hasil penelitian yang telah dilakukan, kemampuan berpikir kritis siswa masih tergolong rendah dengan persentase untuk masing-masing aspek KBK: Memberikan penjelasan dasar (36,80\%); Membangun keterampilan dasar (40,80\%); Inferensi (32,00\%), Membuat penjelasan lebih lanjut $(30,67 \%)$; serta Strategi dan taktik $(36,80 \%)$. Persentase rata-rata kemampuan berpikir kritis siswa adalah $35,41 \%$. Hasil penelitian ini memberikan gambaran mengenai kemampuan berpikir kritis siswa yang masih perlu dilatihkan di dalam pembelajaran. Guru harus mulai berpikir kreatif dan kritis guna membuat rancangan pembelajaran yang dapat melatihkan kemampuan berpikir kritis siswa. Untuk peneliti selanjutnya, sebaiknya dilakukan penindakan lebih lanjut terkait hasil tes kemampuan berpikir kritis melalui wawancara dengan beberapa siswa sebagai bentuk pengecekan kembali terhadap hasil tes.

\section{UCAPAN TERIMAKASIH}

Terimakasih untuk orangtua serta keluarga besar yang sudah membantu baik secara materi dan nonmateri dalam pelaksanaan penelitian ini, kepada dosen Fisika UPI yang sudah membantu dalam pelaksanaan penelitian ini, kepada sekolah yang mengizinkan dilaksanakannya penelitian ini, kepada rekan diskusi, serta kepada semua pihak yang terkait. 


\section{REFERENSI}

[1] Kemendikbud, Peraturan Menteri Pendidikan dan Kebudayaan Republik Indonesia Nomor 81A tahun 2013 tentang Implementasi Kurikulum, Jakarta: Kemendikbud, 2013.

[2] Kemendikbud, Undang - Undang Republik Indonesia Nomor 20 tahun 2003 tentang Sistem Pendidikan Nasional, Jakarta: Kemendikbud, 2003.

[3] D. Ritdamaya and A. Suhandi, "Konstruksi Instrumen Tes Keterampilan Berpikir Kritis Terkait Materi Suhu dan Kalor," Jurnal Penelitian dan Pengembangan Pendidikan Fisika, Vol. 2, No. 2, 2016, pp. 87-96.

[4] J. Lau and J. Chan, "What is Critical Thinking?" in https://philosophy.hku.hk/thinkcritical/ct.php, 2018.

[5] Rahmawati, "Hasil TIMSS 2015 (Diagnosa Hasil untuk Perbaikan Mutu dan Peningkatan Capaian)," in https://puspendik. kemdikbud.go.id./seminar/upload/Hasil\%20Seminar\%20Puspendik\%202016/Rah mawati-Seminar\%20Hasil\%20TIMSS\%202015.pdf., 2018.

[6] Siswoyo and Sunaryo, "High Order Thinking Skills: Analisis Soal dan Implementasinya dalam Pembelajaran Fisika di Sekolah Menengah Atas", Jurnal Penelitian dan Pengembangan Pendidikan Fisika, Vol. 3, No. 1, pp. 11-20.

[7] Kowiyah, “Kemampuan Berpikir Kritis,” Jurnal Pendidikan Dasar, Vol.3, No.5, 2012.

[8] D. J. Treffinger, dkk., Creative Problem Solving: An Introduction, Texas: Prufrock Press Inc., 2006.

[9] R. H. Ennis, "The Nature of Critical Thinking: An Outline of Critical Thinking Dispositions and abilities," Sixth International Conference on Thinking, Cambridge, MA., 2011, pp. 1-8.

[10] S. Nurazizah, P. Sinaga, and A. Jauhari, "Profil Kemampuan Kognitif dan Keterampilan Berpikir Kritis Siswa SMA pada Materi Usaha dan Energi," Jurnal Penelitian dan Pengembangan Pendidikan Fisika, Vol. 3, No. 2, pp. 197-202.

[11] S. Arikunto, Prosedur Penelitian: Suatu Pendekatan Saintifik, Jakarta: Rineka Cipta, 2014.

[12] L. Nuryanti, S. Zubaidah, and M. Diantoro, "Analisis Kemampuan Berpikir Kritis siswa SMP," in Jurnal pendidikan: Teori, Penelitian, dan Pengembangan, 3.2, 2018, pp. 155158.

[13] W. Arini and F. Juliadi, "Kemampuan Berpikir Kritis pada Mata Pelajaran Fisika untuk Pokok Bahasan Vektor Siswa Kelas X SMA Negeri 4 Lubuklinggau, Sumatera Selatan,” Berkala Fisika Indonesia, 10(1), 2018.

[14] H. Fatmawati, Mardiyana, and Triyanto, "Analisis Berpikir Kritis Siswa dalam Pemecahan Masalah Matematika Berdasarkan Polya pada Pokok Bahasan Persamaan Kuadrat (Penelitian pada Siswa Kelas X SMK Muhammadiyah 1 Sragen Tahun Pelajaran 2013/2014)," Jurnal Elektronik Pembelajaran Matematika, 2(9), 2014.

[15] M. Sari, Susiswo, T. Nusantara "Analisis Kemampuan Berpikir Kritis siswa Kelas VII-D SMP Negeri 1 Gambut," Prosiding Seminar Nasional Matematika dan Pendidikan Matematika FKIP UN, 2018, pp. 254-264.

[16] H. Fatmawati, M. Mardiyana, and T. Triyanto, "Analisis Berpikir Kritis siswa dalam pemecahan masalah matematika berdasarkan polya pada pokok bahasan persamaan kuadrat (penelitian pada siswa kelas X SMK Muhammadiyah 1 Sragen tahun pelajaran 2013/2014)," Jurnal Pembelajaran Matematika, 2(9). 2014. 
[17] N. Hestiningsih and S. Sugiharsono, "Peningkatan Kemampuan Berpikir Kritis Peserta Didik Pembelajaran IPS melalui Metode Problem Solving Berbantuan Media Informasi," Harmoni Sosial: Jurnal Pendidikan IPS, 2(1), 2015, pp. 71-86.

[18] H.N. Melida, P. Sinaga, S. Feranie, "Implementasi Strategi Writing to Learn untuk Meningkatkan Kemampuan Kognitif dan Keterampilan Berpikir Kritis Siswa SMA pada Materi Hukum Newton," Jurnal Penelitian dan Pengembangan Pendidikan Fisika," 2(2), 2016, pp. 31-38.

[19] F. Bakri, S. Sunaryo, V. F. Irawan, \& D. Muliyati, "E-Learning Model for Problem Based Learning on Heat and Thermodynamic Topics in High School," Jurnal Penelitian dan Pengembangan Pendidikan Fisika, 4(2), 2018, pp. 101-112.

[20] I.W. Santyasa, "Model-model Pembelajaran Inovatif," in Jurnal Prendidikan Fisika FPMIPA Universitas Pendidikan Ganesha, 2007, pp. 1-16. 